\title{
Possibilities of "Crushing" the Transmission Curve of COVID-19 in Latin America - We Still Have Time
}

\author{
Samuel Pecho-Silva ${ }^{1,2}$ (D) Ana Claudia Navarro-Solsol ${ }^{3}$ (D) Kovy Arteaga-Livias $^{2,4}$ (D), \\ Vicky Panduro-Correa ${ }^{4}$, Kuldeep Dhama ${ }^{5}$ iD and Alfonso J. Rodriguez-Morales ${ }^{2,6,7 *}$ (D)
}

${ }^{1}$ Hospital Nacional Edgardo Rebagliati Martins, Lima, Peru. ${ }^{2}$ Universidad Cientifica del Sur, Lima, Peru. ${ }^{3}$ Universidad Nacional de Ucayali. Pucallpa, Peru. ${ }^{4}$ Facultad de Medicina. Universidad Nacional Hermilio Valdizan. Huanuco, Peru. ${ }^{5}$ Division of Pathology, ICAR-Indian Veterinary Research Institute, Izatnagar 243 122, Bareilly, Uttar Pradesh, India. ${ }^{6}$ Public Health and Infection Research Group, Faculty of Health Sciences, Universidad Tecnologica de Pereira, Pereira, Colombia. ${ }^{7}$ Grupo de Investigacion Biomedicina, Faculty of Medicine, Fundacion Universitaria Autonoma de las Americas, Pereira, Risaralda, Colombia.

\begin{abstract}
Latin America is suppose to have significant advantages over other developing regions, such as Asia and Africa, given the time where the Severe Acute Respiratory Syndrome coronavirus 2 (SARS-CoV-2), causing the Coronavirus Diseases 2019 (COVID-19), arrived, mainly from Europe. This occurred on February 26, 2020. Then, multiple previous measures were taken in order to prevent and mitigate the impact of pandemic in the region. In the current mini-review update we discuss the possibilities of "crushing" the transmission curve of COVID-19 in the region after two months of the arrival of this emerging coronavirus.
\end{abstract}

Keywords: Latin America, SARS-CoV-2, COVID-19, epidemiology, prevention, control

\footnotetext{
*Correspondence: arodriguezm@utp.edu.co

(Received: May 03, 2020; accepted: May 11, 2020)

Citation: Pecho-Silva S, Navarro-Solsol AC, Arteaga-Livias K, et al. Possibilities of "Crushing" the Transmission Curve of COVID-19 in Latin America - We Still Have Time. J Pure Appl Microbiol. 2020;14(suppl 1):713-716. doi: 10.22207/JPAM.14.SPL1.06

(C) The Author(s) 2020. Open Access. This article is distributed under the terms of the Creative Commons Attribution 4.0 International License which permits unrestricted use, sharing, distribution, and reproduction in any medium, provided you give appropriate credit to the original author(s) and the source, provide a link to the Creative Commons license, and indicate if changes were made.
} 


\section{INTRODUCTION}

The first confirmed case of the Severe Acute Respiratory Syndrome coronavirus 2 (SARSCov-2) infection, causing the Coronavirus Diseases 2019 (COVID-19) in Latin America was detected on February 26, 2020, with one case in Brazil, proceeding from Italy. As of May 3, 2020, there have been more than 248,000 confirmed cases in the Latin America and the Caribbean region $(203,097$ in South America) and 13,436 deaths $(6,750 \text { in Brazil) })^{1}$. After analyzing the situation and comparing it with other countries and regions that have dealt with the pandemic in a correct and timely manner, we suggest some measures that may contribute to the "crushing" 2 of the curve in the remaining weeks for social isolation. It would be considered mandatory in most countries that should take serious measures for that.

Suggested measures to "crushing" the curve of COVID-19 in Latin America

In order to control more, to mitigate, to slow down the speed of the transmission in the region, we have analyzed, based on multiple sources, the idea of suggestion of the following measures:

The active search for asymptomatic and symptomatic cases. The countries with the best management of the epidemic have come to take samples of the majority of their population and have not waited for a call to an emergency center to do it. The evaluation must also be active and early for targeted groups such as health personnel without exception, the armed forces, and the police, and for all workers who have continued their work during the period of compulsory isolation, especially those serving the public, such as the staff of supermarkets, pharmacies and the like ${ }^{3}$.

The application of chest CT without contrast both in groups at risk of developing severe forms of the disease or transmitting the infection to others through their work activity, this would help us to know the true state of "asymptomatic" or of "Pre-symptomatic" that appear to be two completely different situations $s^{4,5}$.

The imaging follow-up of all the isolates, through health brigades that perform a pulmonary ultrasound, who can verify day by day the favorable evolution or not of the lung lesions and decide to keep them in isolation or transfer them to a health center ${ }^{6}$.

Isolation of all positive cases by RT-PCR, rapid test, or suggestive chest tomography must be strict and in one-person settings for a minimum of 14 days. This mandatory isolation of cases cannot be in the patient's home or with other positive cases, because it has already been described that overexposure to the virus is a risk factor for poor evolution, with compliance control of the mandatory isolation through geolocation (GPS) ${ }^{7}$. For this purpose, hotels that are currently empty in the different cities of the region or sports venues can be equipped, such as the sports village of Peru, built for the Pan American Games, currently little occupied. These areas of isolation can also be used by health professionals who do not want to be in contact with their families because they are afraid of infecting them.

Their authorities must fully protect health personnel facing this pandemic through legal initiatives that include: declaration of occupational disease, respect for their employment status, employment contracts for new and old with all the benefits of law without distinction, the creation of life insurance thought and calculated to cover the family and relatives in case of death or complications for the rest of life ${ }^{8}$.

It is important for the evaluation and follow-up of all the recovered cases before the possibility of the use of their antibodies, the evaluation of the viral load, and the knowledge of the pathophysiology of the disease ${ }^{9,10}$ there are no approved specific antiviral agents for novel coronavirus disease 2019 (COVID-19.

Implement areas with negative pressure where aerosol-generating procedures are carried out, and the continuous supply of personal protective equipment for health personnel must be guaranteed. We must aspire to follow the highest international standards in this regard. In essence, the use of certified N95 respirators must be massive by health personnel, and in areas where aerosols are produced, at least FPP3 respirators must be used ${ }^{11}$.

We must not neglect the general population. Therefore we must carry out massive educational campaigns on the correct use of masks in public places, in addition to the well-known 
cough hygiene measures, social distancing, and voluntary isolation in case of symptoms ${ }^{7}$.

Actively evaluate people over 60 or with comorbidities in their homes, rest homes, nursing homes, shelters, and centers for the elderly. The personnel in charge of their care must be periodically evaluated through RT-PCR, and rapid tests and external visits must be restricted. The use of masks should be mandatory for caregivers ${ }^{12}$.

"Clean" hospitals should be designated to centralize pediatrics, gynecology, urgent surgeries, and medicine, transferring to them patients who cannot be discharged and who do not have an infection, being evaluated by general practitioners or specialists not related to caring of patients with COVID-19. Hospitals with intensive care units and mechanical ventilators and qualified personnel for their use will receive patients with COVID- $19^{13}$ the severe acute respiratory syndrome coronavirus 2 (SARS-CoV-2). Besides, it is also important to have a personal and protocolized medical history for patients with COVID-19 that serves for rapid decision-making and better case management ${ }^{14}$.

\section{DISCUSSION}

We still have time to implement many of the measures that protect our region. We are optimistic, and we believe that if governments continue to listen to the voices of the academy, they will be able to make the curve "crushed" very soon. Countries in the region, such as Brazil ${ }^{15}$, are facing a critical situation as the pandemic advance, given the massive number of cases reported week after week. But in others, as is the case of Ecuador, the number of fatalities, coupled with the lack of intensive care units (ICU) beds, seems to be critical for the health care, as well as complex with the overlapping of other epidemics, such as dengue ${ }^{16}$.

Multiple implications related to healthcare situation at the arrival of this pandemic disease, including other epidemics, such as malaria and measles, related to Venezuela forced migration, highlight the complex crisis of the region ${ }^{17,18}$.

Finally, we need to increase the diagnostic capacity in the region, in order to increase the number of RT-PCR for SARS-CoV-2 performed in order to better approach to the real epidemiological situation of Latin America ${ }^{19,20}$. Whilst we wait an effective vaccine, the best control is preventive measures, as those suggested in this mini-review ${ }^{20}$.

\section{ACKNOWLEDGMENTS}

None.

\section{CONFLICT OF INTEREST}

The listed author(s) declare no conflict of interest in any capacity, including competing or financial.

\section{AUTHORS' CONTRIBUTION}

SPS conceived the idea of the MiniReview. SPS, KAL and AJRM performed a review of the literature on the topic related; all authors read the cited literature; KAL developed the first draft of the manuscript; all authors contributed consequently with newer versions; all authors approved the final submitted version.

\section{FUNDING}

None.

\section{ETHICS STATEMENT}

This article does not contain any studies with human participants or animals performed by any of the authors.

\section{AVAILABILITY OF DATA}

Not applicable.

\section{REFERENCES}

1. Coronavirus Update (Live): $1,998,111$ Cases and 126,604 Deaths from COVID-19 Virus Pandemic - Worldometer. https://www.worldometers.info/ coronavirus/. Accessed April 14, 2020.

2. Nussbaumer-Streit B, Mayr V, Dobrescu Al, et al. Quarantine alone or in combination with other public health measures to control COVID-19: a rapid review. Cochrane Database Syst Rev. 2020;4:CD013574. https://doi.org/10.1002/14651858.CD013574

3. Xiong $P, X u K$. How to deal with 2019 novel coronavirus (COVID-19): a public health practice from the Centers for Disease Control and Prevention in Zhanggong District, Ganzhou City, China. Infect Control Hosp Epidemiol. April 2020; 1-5. https://doi.org/10.1017/ ice.2020.110

4. Long $\mathrm{C}, \mathrm{XuH}$, Shen $\mathrm{Q}$, et al. Diagnosis of the Coronavirus disease (COVID-19): rRT-PCR or CT? Eur J Radiol. 2020; 126: 108961. https://doi.org/10.1016/j. ejrad.2020.108961

5. Cheng MP, Papenburg J, Desjardins M, et al. Diagnostic Testing for Severe Acute Respiratory Syndrome-Related Coronavirus-2: A Narrative Review. Ann Intern Med., 2020. https://doi.org/10.7326/M20-1301

6. Peng $\mathrm{Q}-\mathrm{Y}$, Wang $\mathrm{X}-\mathrm{T}$, Zhang $\mathrm{L}-\mathrm{N}$, Chinese Critical Care Ultrasound Study Group (CCUSG). Using echocardiography to guide the treatment of novel 
coronavirus pneumonia. Crit Care Lond Engl. 2020; 24(1): 143. https://doi.org/10.1186/s13054-02002856-z

7. Adhikari SP, Meng S, Wu Y-J, et al. Epidemiology, causes, clinical manifestation and diagnosis, prevention and control of coronavirus disease (COVID-19) during the early outbreak period: a scoping review. Infect Dis Poverty. 2020;9(1):29. https://doi.org/10.1186/ s40249-020-00646-x

8. Durant CG. Coronavirus: una alternativa al martillo y el baile. Medium. https://medium.com/@cganoza/ coronavirus-una-alternativa-al-martillo-y-el-bailed3309ebcb789. Published April 12, 2020. Accessed April 14, 2020.

9. Lipsitch $M$, Swerdlow DL, Finelli L. Defining the Epidemiology of Covid-19 - Studies Needed. N Engl J Med. 2020;382(13):1194-1196. https://doi. org/10.1056/NEJMp2002125

10. Duan K, Liu B, Li C, et al. Effectiveness of convalescent plasma therapy in severe COVID-19 patients. Proc Natl Acad Sci U S A. 2020. https://doi.org/10.1073/ pnas. 2004168117

11. Cook TM. Personal protective equipment during the COVID-19 pandemic - a narrative review. Anaesthesia. 2020. https://doi.org/10.1111/anae.15071

12. Tian $\mathrm{H}$, Liu Y, Li Y, et al. An investigation of transmission control measures during the first 50 days of the COVID-19 epidemic in China. Science. 2020. https:// doi.org/10.1126/science.abb6105

13. Zangrillo A, Beretta L, Silvani $P$, et al. Fast reshaping of intensive care unit facilities in a large metropolitan hospital in Milan, Italy: facing the COVID-19 pandemic emergency. Crit Care Resusc J Australas Acad Crit Care Med.2020.

14. Fineberg HV. Ten Weeks to Crush the Curve. N Engl J Med. 2020. https://doi.org/10.1056/NEJMe2007263

15. Cimerman S, Chebabo A, da Cunha CA, RodriguezMorales AJ. Deep Impact of COVID-19 in the Health Care of Latin America: the case of Brazil. Braz J Infect Dis. 2020. https://doi.org/10.1016/j.bjid.2020.04.005

16. Navarro J-C, Arrivillaga-Henriquez J, Salazar-Loor J, Rodriguez-Morales AJ. COVID-19 and Dengue, coepidemics in Ecuador and other countries in Latin America: pushing strained health care systems over the edge. Travel Med Infect Dis. 2020. https://doi. org/10.1016/j.tmaid.2020.101656

17. Rodriguez-Morales AJ, Sanchez-Duque JA, HernandezBotero S, et al. (LANCOVID19) Latin American Network of Coronavirus Disease 2019-COVID-19 Research. Preparacion y control de la enfermedad por coronavirus 2019 (COVID-19) en America Latina. Acta Medica Peruana 2020;37(1):3-7. https://doi. org/10.35663/amp.2020.371.909

18. Rodriguez-Morales AJ, Gallego V, Escalera-Antezana JP, et al. COVID-19 in Latin America: the implications of the first confirmed case in Brazil. Travel Med Infect Dis. 2020. https://doi.org/10.1016/j.tmaid.2020.101613

19. Pathak M, Patel SK, Rana J, Tet al. The Global Threat of SARS-CoV-2/COVID-19 and the Need for More and Better Diagnostic Tools. Arch Med Res. 2020. https:// doi.org/10.1016/j.arcmed.2020.04.003

20. Patel SK, Pathak M, Tiwari R, et al. Bonilla-Aldana DK, Rodriguez-Morales AJ. A vaccine is not too far for COVID-19. J Infect Dev Ctries. 2020 (accepted, in press). 